\title{
Essential metals, vitamins and antioxidant enzyme activities in COVID-19 patients and their potential associations with the disease severity
}

\author{
Iman Al-Saleh $(\mathbb{D} \cdot$ Nujud Alrushud • Hissah Alnuwaysir • Rola Elkhatib • \\ Mohamed Shoukri · Fouad Aldayel • Razan Bakheet - Maha Almozaini
}

Received: 11 August 2021/ Accepted: 25 November 2021 / Published online: 7 January 2022

(C) The Author(s), under exclusive licence to Springer Nature B.V. 2021

\begin{abstract}
The role of micronutrient deficiency in the pathogenesis of COVID-19 has been reviewed in the literature; however, the data are limited and conflicting. This study investigated the association between the status of essential metals, vitamins, and antioxidant enzyme activities in COVID-19 patients and disease severity. We recruited 155 patients, who were grouped into four classes based on the Adults guideline for the Management of Coronavirus Disease 2019 at King Faisal Specialist \& Research Centre (KFSH\&RC): asymptomatic $(N=16), \quad$ mild $(N=49)$, moderate $(N=68)$, and severe $(N=22)$. We measured serum levels of copper $(\mathrm{Cu})$, zinc $(\mathrm{Zn})$, selenium (Se), vitamin $\mathrm{D}_{3}$, vitamin $\mathrm{A}$, vitamin $\mathrm{E}$, total antioxidant capacity, and superoxide dismutase (SOD). Among the patients, 30\%, 25\%, 37\%, and
\end{abstract}

I. Al-Saleh $(\bowtie) \cdot N$. Alrushud · H. Alnuwaysir .

R. Elkhatib

Environmental Health Program, King Faisal Specialist

Hospital and Research Centre,

PO Box: 3354, Riyadh 11211, Saudi Arabia

e-mail: iman@kfshrc.edu.sa

M. Shoukri

Department of Epidemiology and Biostatistics, Schulich

School of Medicine and Dentistry, University of Western

Ontario, London, ON, Canada

F. Aldayel

Department of Pathology and Laboratory Medicine, King Faisal Specialist Hospital and Research Centre, Riyadh,

Saudi Arabia
$68 \%$ were deficient in Se $(<70.08 \mu \mathrm{g} / \mathrm{L}), \mathrm{Zn}$ $(<0.693 \mu \mathrm{g} / \mathrm{mL})$, vitamin A $(<0.343 \mu \mathrm{g} / \mathrm{mL})$, and vitamin $\mathrm{D}_{3}(<20.05 \mu \mathrm{g} / \mathrm{L})$, respectively, and SOD activity was low. Among the patients, $28 \%$ had elevated $\mathrm{Cu}$ levels $(>1.401 \mu \mathrm{g} / \mathrm{mL}, \mathrm{KFSH} \& \mathrm{RC}$ upper reference limit). Multiple regression analysis revealed an $18 \%$ decrease in Se levels in patients with severe symptoms, which increased to $30 \%$ after adjusting the model for inflammatory markers. Regardless of inflammation, Se was independently associated with COVID-19 severity. In contrast, a $50 \%$ increase in $\mathrm{Cu}$ levels was associated with disease severity only after adjusting for C-reactive protein, reflecting its possible inflammatory and pro-oxidant role in COVID-19 pathogenesis. We noted an imbalance in the ratio between $\mathrm{Cu}$ and $\mathrm{Zn}$, with $\sim 83 \%$ of

\footnotetext{
R. Bakheet

Translational Genomics Department, King Faisal Specialist Hospital and Research Centre, Riyadh, Saudi Arabia

M. Almozaini

Department of Infection and Immunity, King Faisal Specialist Hospital and Research Centre, Riyadh, Saudi Arabia
} 
patients having a $\mathrm{Cu} / \mathrm{Zn}$ ratio $>1$, which is an indicator of inflammation. Cu-to- $\mathrm{Zn}$ ratio increased to $45 \%$ in patients with mild symptoms and $34 \%-36 \%$ in patients with moderate symptoms compared to asymptomatic patients. These relationships were only obtained when one of the laboratory parameters (lymphocyte or monocyte) or inflammatory markers (neutrophil-to-lymphocyte ratio) was included in the regression model. These findings suggest that $\mathrm{Cu} / \mathrm{Zn}$ might further exacerbate inflammation in COVID-19 patients and might be synergistically associated with disease severity. A $23 \%$ decrease in vitamin A was seen in patients with severe symptoms, which disappeared after adjusting for inflammatory markers. This finding may highlight the potential role of inflammation in mediating the relationship between COVID-19 severity and vitamin A levels. Despite our patients' low status of $\mathrm{Zn}$, vitamin $\mathrm{D}_{3}$, and antioxidant enzyme (SOD), there is no evidence of their role in COVID-19 progression. Our findings reinforce that deficiency or excess of certain micronutrients plays a role in the pathogenesis of COVID-19. More studies are required to support our results.

Keywords COVID-19 - Essential metals . Vitamins · Antioxidant activity · Disease severity

\section{Introduction}

In December 2019, a severe acute respiratory syndrome caused by coronavirus-2 (SARS-CoV-2) emerged in Wuhan City, China and subsequently spread to many other countries around the globe. The disease was named COVID-19 by the World Health Organization (WHO). Coronaviruses are enveloped, positive single-stranded RNA viruses that infect humans and a wide range of animals and belong to different subfamilies: alpha, beta, gamma, and delta (Yu et al. 2020). Coronavirus-2 is a betacoronavirus and is similar to the coronaviruses that cause a severe acute respiratory syndrome in bats (Chan et al. 2020a, b). Due to its worldwide spread, WHO declared a pandemic on March 11th, 2020. By April 4th, 2020 (when this study was planned), there were 1,051,635 cases and 56,985 deaths from more than 180 countries. The total number of confirmed cases in Saudi Arabia was 2039 (https://www.who.int/emergencies/ diseases/novel-coronavirus-2019/situation-reports).

COVID-19 is a highly transmissible and pathogenic virus that may cause severe respiratory illness leading to intensive care unit admission and high mortality (Guan et al. 2020; Chan et al. 2020a, b). However, the disease may be asymptomatic or mildly symptomatic in more than $80 \%$ of patients, with the rest exhibiting severe or critical symptoms (Wu and McGoogan 2020). The immune system protects the body from infectious microorganisms (Sattler 2017). Viral factors (e.g., type, mutation, viral load, viral titer, and in vitro viability) and the individual's immune system (e.g., genetics, age, gender, nutritional status, neuroendocrine-immune regulation, and physical condition) contribute to both the duration and severity of the disease ( $\mathrm{Li}$ et al. 2020a, b). Studies have emphasized the role of the innate immune response to coronavirus infection by inhibiting its replication, promoting its clearance, inducing tissue repair, and triggering a prolonged adaptive immune response $(\mathrm{Li}$ et al. 2020a, b).

Micronutrients such as vitamins A, D, C, E, B 6 , and $\mathrm{B}_{12}$, folate, zinc $(\mathrm{Zn})$, iron, copper $(\mathrm{Cu})$, and selenium (Se) play vital roles in maintaining a responsive immune system. Inadequate dietary intakes may increase the risk of infection (Gombart et al. 2020). In the absence of a treatment or vaccine for COVID-19 at its early onset, researchers have recommended nutritional interventions for COVID-19 patients with micronutrient deficiencies (Zhang and Liu 2020). According to Shi et al. (2020), the immune response to COVID-19 goes through two phases: (1) an immune defense-based protective phase and (2) an inflammation-driven damaging phase. Due to its lung protective properties, vitamin $\mathrm{B}_{3}$ should be administered as soon as the patient begins to cough. At the time of this research, no studies confirmed our hypothesis that adequate serum levels of micronutrients in patients infected with COVID-19 might be associated with milder disease symptoms and optimal immune response. Several reviews have focused on nutrient status and COVID-19 severity, with vitamin D being the most studies (Oscanoa et al. 2021; Khatiwada and Subedi 2021; Domingo and Marquès 2021; Fedele et al. 2021); however, clinical studies based on laboratory analyses are limited and controversial (Campi et al. 2021; Skalny et al. 2021; Zeng et al. 2021b; Gonçalves et al. 2021). 
Abnormalities in total white blood count, neutrophil, lymphocyte, monocyte, eosinophil, C-reactive protein and other hematological parameters were reported in COVID-19 patients. These abnormalities need to be monitored for potential disease progression (Henry et al. 2020). Researchers recommend the use of biomarkers of inflammation derived from differential counts such as ratios of neutrophil to lymphocyte, neutrophil to monocyte, and lymphocyte to monocyte as inflammatory prognostic markers for several diseases, including COVID-19 (Man et al. 2021; Anurag et al. 2020).

The objectives of our study were to (1) assess the levels of micronutrients $(\mathrm{Cu}, \mathrm{Zn}$, Se, vitamin A, vitamin $\mathrm{E}$, and vitamin $\mathrm{D}_{3}$ ) and antioxidant enzyme activities in COVID-19 patients; and (2) determine their potential association with disease severity after adjusting for specific laboratory parameters or inflammatory biomarkers. The results of our study might emphasize the importance of nutritional interventions as treatment strategies to control the spread and severity of COVID-19.

\section{Materials and methods}

Study participants

Between June 3rd and July 11th, 2020, we recruited 155 patients ( $\geq 18$ years old) that were infected with COVID-19 according to the Pathology and Laboratory Medicine Department at KFSH\&RC. We obtained verbal and written consent from all patients. KFSH\&RC Research Ethics Committee (RAC\# 2200025) approved the study. Before treatment, we collected all samples. We obtained information on demographics, lifestyle, medical history, white blood cells (WBCs), differential counts (neutrophils [NEUT], lymphocytes [LYM], and monocytes [MONO]), immunology (ferritin [FER] and C-reactive protein [CRP]) from the patients' electronic medical reports. We calculated the ratios between NEUT and LYM (NLR), NEUT and MONO (NMR), and LYM and MONO (LMR). The Clinical Biochemistry, Pathology and Laboratory Medicine Department of KFSH\&RC conducted the tests. Disease severity was classified into four groups based on the KFSH\&RC Adult Guidelines for the Management of Coronavirus Disease 2019 (Table 1).
Metal assessment

We diluted $(50 \times)$ of each serum sample $(50 \mu \mathrm{L})$ with a diluent, a mixture of $0.5 \%$ nitric acid (Fisher Scientific, PA), $0.05 \%$ Triton-X (Sigma-Aldrich ${ }^{\mathrm{TM}}$, MO), 2\% methanol (Fisher Scientific, PA; all v/v), rubidium as an internal standard at $1 \mu \mathrm{g} / \mathrm{L}$ for $\mathrm{Zn}$ and $\mathrm{Cu}$ and $0.1 \mu \mathrm{g} / \mathrm{L}$ for Se. We measured metals levels by inductively coupled plasma-mass spectrometry (ICPMS; Perkin Elmer NexION® 2000). The diluent's intensity for each metal was subtracted from calibrator standards, quality control, and patient samples. We prepared calibration standards in serum with every batch of patient samples at 4-60 $\mu \mathrm{g} / \mathrm{L}(\mathrm{Zn}), 6-60 \mu \mathrm{g} / \mathrm{L}$ $(\mathrm{Cu})$, and $0.5-10 \mu \mathrm{g} / \mathrm{L}(\mathrm{Se})$. These ranges showed satisfactory linearity, with linear correlation coefficients $\left(\mathrm{r}^{2}\right) \quad$ of $\quad 0.9981 \pm 0.0025 \quad(\mathrm{Zn})$ and $0.9998 \pm 0.0003(\mathrm{Cu})$ from five independent runs. For Se, $\mathrm{r}^{2}$ was $0.9998 \pm 0.0001$ from four independent runs. We evaluated the accuracy of the method using both external assurance reference materials and internal quality control samples. Our analytical results for UTAK 66,816 reference serum normal range (UTAK Laboratories Inc., CA) were $730.22 \pm 61.822 \mu \mathrm{g} / \mathrm{L}(\mathrm{Zn}), 1041.59 \pm 31.42 \mu \mathrm{g} / \mathrm{L}$ $(\mathrm{Cu})$, and $104.97 \pm 0.347 \mu \mathrm{g} / \mathrm{L}(\mathrm{Se})$. These values were within $\pm 15 \%$ of the UTAK certified reference values of $650 \mu \mathrm{g} / \mathrm{L}(\mathrm{Zn}), 1110 \mu \mathrm{g} / \mathrm{L}(\mathrm{Cu})$, and $105 \mu \mathrm{g} /$ $\mathrm{L}$ (Se). Pooled serum samples spiked with three different $\mathrm{Zn}, \mathrm{Cu}$, and $\mathrm{Se}$ levels were analyzed in parallel with patient samples to check between-run precision. The average recoveries from five runs of pooled serum samples spiked with 10,15 , and $30 \mu \mathrm{g} / \mathrm{L}$ $\mathrm{Zn}$ were $98.8 \pm 9.8 \%, \quad 102.9 \pm 4.6 \%$, and $100.5 \pm 2.4 \%$, respectively. For spiked serum samples with 20,40 , and $50 \mu \mathrm{g} / \mathrm{L} \mathrm{Cu}$, the average recoveries from five runs were $106.0 \pm 5.9 \%$, $103.4 \pm 3.4 \%$, and $101.3 \pm 2.8 \%$, respectively. The average recoveries from four runs of serum samples spiked with $0.75,1.5$, and $3 \mu \mathrm{g} / \mathrm{L}$ Se were $106.2 \pm 6.3 \%, 103.9 \pm 3.5 \%$, and $101.3 \pm 1.7 \%$, respectively. The within-run precision relative standard deviations (\% RSD) values for ten replicates of pooled serum samples spiked with 10,15 , and $30 \mu \mathrm{g} / \mathrm{L}$ zinc were $9.0,4.1$, and $4.8 \%$, respectively. From ten runs of 20,40 , and $50.0 \mu \mathrm{g} / \mathrm{L} \mathrm{Cu}, \%$ RSD was $4.2,3.9$, and $1.6 \%$, respectively. Finally, \% RSD for ten replicates of $0.75,1.5$, and $3.0 \mu \mathrm{g} / \mathrm{L}$ Se was $2.8,3.2$, and $2.2 \%$, respectively. The method detection limit 
Table 1 Classification of COVID-19 severity

\begin{tabular}{|c|c|c|c|}
\hline Asymptomatic & Mild & Moderate & Severe \\
\hline $\begin{array}{l}\text { Patients with no } \\
\text { signs or } \\
\text { symptoms of } \\
\text { infection }\end{array}$ & $\begin{array}{l}\text { Patients with upper respiratory tract } \\
\text { infection symptoms and other mild } \\
\text { symptoms (including fever and } \\
\text { gastrointestinal symptoms) without } \\
\text { evidence of pneumonia }\end{array}$ & $\begin{array}{l}\text { Patients with hypoxia with oxygen } \\
\text { saturation less than } 93 \% \text { at rest or } \\
\text { presence of pneumonia not } \\
\text { requiring ICU admission }\end{array}$ & $\begin{array}{l}\text { Patients with pneumonia } \\
\text { requiring ICU admission or } \\
\text { any of the following: } \\
\text { Respiratory rate of } 30 \\
\text { breaths/min } \\
\text { Arterial oxygen partial } \\
\text { pressure to fractional } \\
\text { inspiratory oxygen ratio } \\
\text { (PaO2/FiO2) } \\
\text { Less than } 300 \\
\text { More than } 50 \% \text { lung } \\
\text { involvement on imaging } \\
\text { within } 24-48 \mathrm{~h} \\
\text { Critical respiratory failure } \\
\text { requiring mechanical } \\
\text { ventilation, septic shock or } \\
\text { multiorgan dysfunction }\end{array}$ \\
\hline
\end{tabular}

(MDL) was calculated by multiplying the standard deviation (SD) of 10 replicates of the blank levels and the Student's $t$-value corresponding to $N-1$ degrees of freedom and 99th percentile. Serum MDLs for Zn, $\mathrm{Cu}$, and $\mathrm{Se}$ were 1.707, 0.767, and $0.079 \mu \mathrm{g} / \mathrm{L}$, respectively.

\section{Vitamin analysis}

We quantitatively assessed vitamins $\mathrm{A}, \mathrm{E}$, and $\mathrm{D}_{3}$ using the Chromsystems reagent kit (Chromsystems Instruments \& Chemicals $\mathrm{GmbH}$, Heimburgstrasse, Munich, Germany). The manufacturers provided all materials and reagents. The assays were performed following the supplier's protocols.

Vitamin A (retinol) and vitamin E ( $\alpha$-tocopherol)

In a light-protected reaction vial, we mixed $200 \mu \mathrm{L}$ serum sample, $20 \mu \mathrm{L}$ internal standard, and $25 \mu \mathrm{L}$ precipitation reagent I using a vortex for $30 \mathrm{~s}$. Following the addition of $400 \mu \mathrm{L}$ precipitation reagent II, we mixed the solution for $30 \mathrm{~s}$ and centrifuged it at $9000 \mathrm{~g}$ for $10 \mathrm{~min}$. An aliquot of supernatant was injected onto the $\mathrm{C}_{18}$ reverse-phase high-performance liquid chromatography (HPLC) column connected to the Alliance Waters HPLC 2695 system and a ultra-violet (UV) detector (Waters
Corp., Milford, MA) at $325 \mathrm{~nm}$ switched after $3.5 \mathrm{~min}$ to $295 \mathrm{~nm}$. The flow was maintained at $1.5 \mathrm{~mL} / \mathrm{min}$. The analysis time took $\sim 9 \mathrm{~min}$. The calibration was performed using a lyophilized serum calibration standard with a known concentration of vitamin A $(0.66 \mathrm{mg} / \mathrm{L})$ and vitamin $\mathrm{E}(10.7 \mathrm{mg} / \mathrm{L})$. We used level I and II vitamin A and E lyophilized serum samples as quality controls to monitor the accuracy and precision of the analytical method. From two independent runs, vitamin A concentrations were 0.485 and $0.515 \mathrm{mg} / \mathrm{L}$ (level I) and 1.055 and $1.12 \mathrm{mg} / \mathrm{L}$ (level II). Both were within the certified reference values provided by the manufacturer: $0.35-0.53 \mathrm{mg} / \mathrm{L}$ (level I) and 1.06-1.58 mg/L (level II). From two independent runs, vitamin E concentrations were 7.974 and $8.018 \mathrm{mg} / \mathrm{L}$ (level I) and 14.52 and $14.6 \mathrm{mg} / \mathrm{L}$ (level II). Both were within the certified reference values of $6.83-10.2 \mathrm{mg} / \mathrm{L}$ (level I) and $14.9-22.3 \mathrm{mg} / \mathrm{L}$ (level II).

\section{Vitamin $\mathrm{D}_{3}\left(25-\mathrm{OH}\right.$-vitamin $\left.\mathrm{D}_{3}\right)$}

In a reaction vial, we mixed $100 \mu \mathrm{L}$ sample (serum/calibrator/quality controls), $25 \mu \mathrm{L}$ precipitation reagent, and $200 \mu \mathrm{L}$ internal standard for $20 \mathrm{~s}$ using a vortex and centrifuged the sample at $15,000 \times g$ for $5 \mathrm{~min}$. An aliquot of supernatant $(200 \mu \mathrm{L})$ was transferred into an auto-sampler vial, 
and $50 \mu \mathrm{L}$ was analyzed by ultra-performance liquid chromatography (UPLC)-tandem mass spectrometry (LC-MS/MS; Waters, Milford, MA, USA). Mobile phases (A and B) were independently used in isocratic mode. The total run time was $5 \mathrm{~min}$. We performed the calibration using a lyophilized serum calibration standard of known concentration of vitamin $\mathrm{D}_{3}$ (4.93, 31.8, and $60.4 \mu \mathrm{g} / \mathrm{L})$. From two independent runs, the concentration of vitamin $\mathrm{D}_{3}$ in lyophilized serum quality control concentrations was 9.57 and $10.54 \mu \mathrm{g} / \mathrm{L}$ (low), 30.81 and $32.3 \mu \mathrm{g} / \mathrm{L}$ (medium), and 108.82 and $116.44 \mu \mathrm{g} / \mathrm{L}$ (high). The three ranges were within the certified reference values provided by the company: $12.8-19.2 \mu \mathrm{g} / \mathrm{L}$ (low), 27.5-41.2 $\mu \mathrm{g} / \mathrm{L}$ (medium), and 80.6-121 $\mu \mathrm{g} / \mathrm{L}$ (high).

\section{Antioxidant enzyme activities}

We used the OxiSelect ${ }^{\mathrm{TM}}$ Total Antioxidant Capacity (TAC) assay kit (STA-360) from Cell Biolabs, Inc. (San Diego, CA, USA) according to the manufacturer's protocol. We diluted $20 \mu \mathrm{L}$ of serum sample and standard with $1 \times$ reaction buffer. We measured absorbance at $490 \mathrm{~nm}$. Copper ion reagent was added and incubated for $5 \mathrm{~min}$. The reaction was terminated with a $1 \times$ stop solution, and absorbance was measured at $490 \mathrm{~nm}$. We calculated TAC in samples by comparing their net optical density values to the uric acid standard curve $(0-1 \mathrm{mM})$. Results were expressed as $\mu \mathrm{M}$ copper reducing equivalents.

We measured superoxide anions using the OxiSelect $^{\mathrm{TM}}$ Superoxide Dismutase Activity (SOD) assay kit (STA-340) from Cell Biolabs, Inc. (San Diego, CA, USA). In a 96-well plate, following the addition of $10 \mu \mathrm{L}$ serum and standard diluted with $1 \mathrm{X}$ xanthine oxidase, we mixed and incubated the sample for $1 \mathrm{~h}$ at $37{ }^{\circ} \mathrm{C}$. The standard range was $0-5 \mathrm{U} / \mu \mathrm{L}$. We measured enzyme activity as a function of optical density by the degree of inhibition at $490 \mathrm{~nm}$ and expressed as units $/ \mu \mathrm{L}$. One unit of activity was considered as the concentration that resulted in $50 \%$ inhibition of the reaction.

For both TAC and SOD, we measured absorbance in a Biotek $^{\mathrm{TM}} \mathrm{EL} \times 800^{\mathrm{TM}}$ absorbance microplate reader (Winooski, VT, USA).
Statistical analysis

We presented continuous variables as mean, standard deviation (SD), median, minimum, and maximum and categorical variables as percentages. The analytes were transformed to the natural logarithm (ln) to approximate a normal distribution. Bivariate analyses such as the Mann-Whitney U test, Kruskal-Wallis test, or Chi-square statistic ( $\chi^{2}$ test or Fisher exact test) were used for categorical variables. We performed Spearman rank correlation analyses to assess associations between pairs of continuous variables to identify potential risk factors/confounders of analytes and COVID-19 severity. Separate multiple linear regression models were generated to examine the contribution of each analyte to COVID-19 severity. We created three dummy variables for the four classes of COVID-19 severity, in which one group became the reference group, and all other groups were compared to it. The asymptomatic category was used as a reference group. We adjusted each model for risk factors/confounders that were associated with COVID-19 severity and/or analytes $(p<0.1)$. Due to collinearity, each laboratory marker was entered individually in the model. We expressed the results as the value of $\beta$-standardized regression coefficients, 95\% confidence intervals (CIs) as effect estimates, and $p$-values to assess statistical significance. $\beta$ was presented as a percentage change. SPSS software (version 20; IBM, Armonk, NY, USA) was used for data analysis, and $p<0.05$ was considered statistically significant. Due to the exploratory nature of this study, we also defined $p<0.1$ as marginally significant (Weitkunat and Wildner 2002; Wilhelm et al. 2015).

\section{Results}

Basic characteristics of patients

In this study, we enrolled 155 patients (age range: 18-95 years with a median age of 50). The ratio of females to males was 78 to 77 . The majority were Saudi $(N=139)$, and the rest $(N=16)$ were from different nationalities. Among the 155 patients, five were smokers, seven were former smokers, and 143 were nonsmokers. Approximately $89 \%(N=138)$ had various health problems, some with severe clinical 


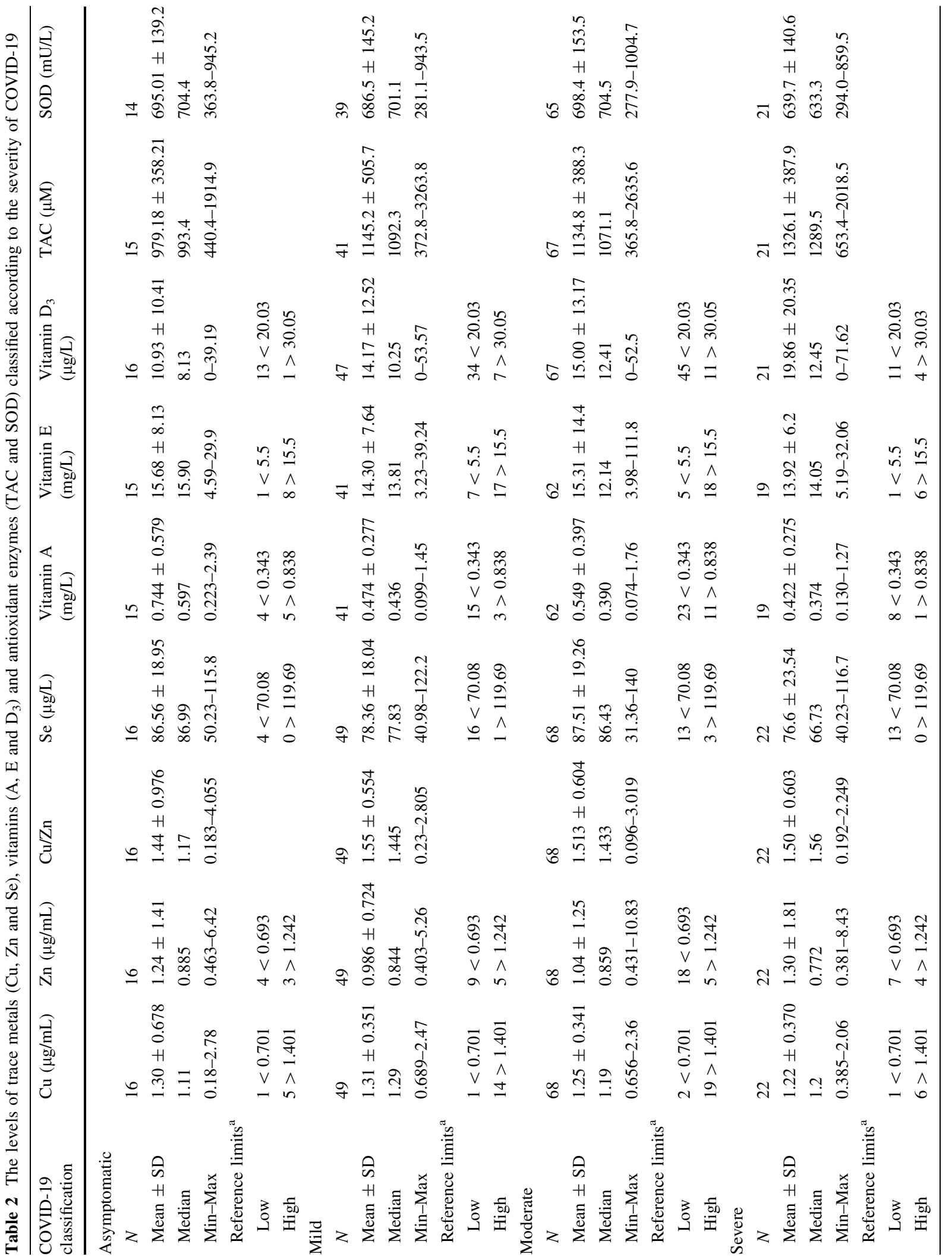




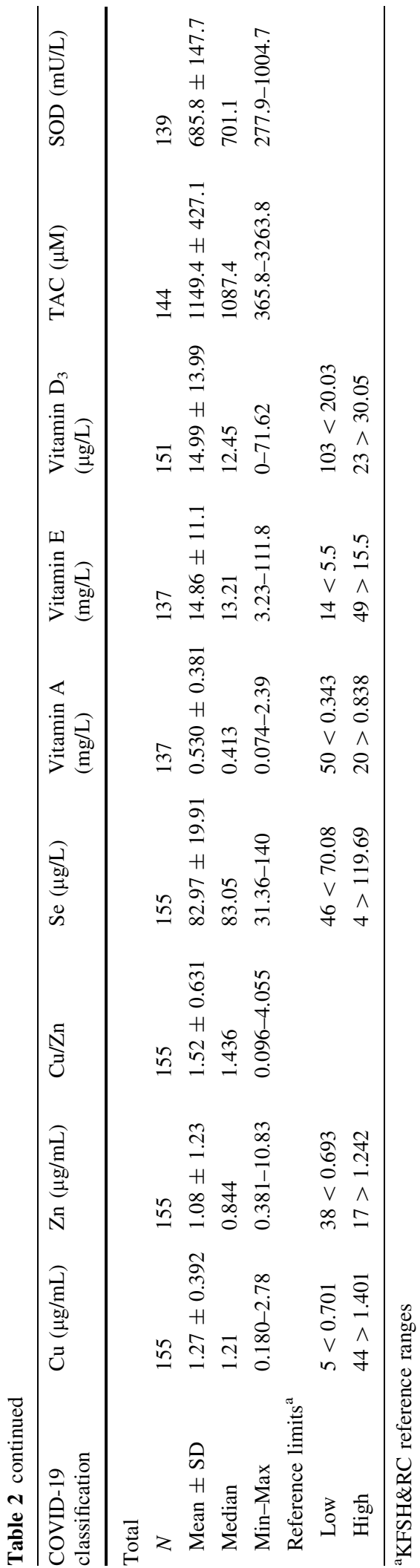

conditions such as cancer $(N=29)$ and organ transplant $(N=18)$. The median body mass index (BMI) was $28.5 \mathrm{~kg} / \mathrm{m}^{2}$ (range: 11.1 to $51.7 \mathrm{~kg} / \mathrm{m}^{2}$ ). BMI was higher in females $\left(31.2 \mathrm{~kg} / \mathrm{m}^{2}\right)$ than in males $(26.9 \mathrm{~kg} /$ $\left.\mathrm{m}^{2} ; p=0.004\right)$. According to the World Health Organization's BMI classification, the prevalence of obesity (BMI $\geq 30 \mathrm{~kg} / \mathrm{m}^{2}$ ) and overweight (BMI $\geq 25 \mathrm{~kg} / \mathrm{m}^{2}$ ) and underweight $\left(\mathrm{BMI}<18.5 \mathrm{~kg} / \mathrm{m}^{2}\right.$ ) among our patients was 44.8, 75.3 and $1.29 \%$, respectively https://www.who.int/data/gho/data/ themes/theme-details/GHO/body-mass-index-(bmi).

Among the 155 patients, 78 (50.3\%) had no fever at diagnosis, $129(83.2 \%)$ were admitted to the hospital for 1-113 days, and $26(16.8 \%)$ were isolated at home. Sixteen patients $(10.3 \%)$ died during the study. Ninety-nine $(63.9 \%)$ patients took supplements including vitamin D (37) and minerals (15). Based on the COVID-19 symptoms exhibited at admission, 16 (10.3\%), 49 (31.6\%), 68 (43.9\%), and $22(14.2 \%)$ patients were classified as asymptomatic, mild, moderate, and severe, respectively.

There were 34 (21.9\%), 4, 61, 7, 6, 10, and 6 patients with WBC, NEUT, LYM, MONO, CRP, and FER less than the lower KFSH\&RC reference limit $3.9 \times 10^{9} / \mathrm{L}, 30 \%, 23 \%, 4 \%, 3 \mathrm{mg} / \mathrm{L}$, and $30 \mu \mathrm{g} / \mathrm{L}$, respectively. In contrast, $8,47,3,44,88$, and 46 patients had WBC, NEUT, LYM, MONO, CRP, and FER higher than the upper KFSH\&RC reference limit of $11 \times 10^{9} / \mathrm{L}, 70 \%, 60 \%, 12 \%, 3 \mathrm{mg} / \mathrm{L}$, and $400 \mu \mathrm{g} /$ $\mathrm{L}$, respectively.

Trace element, vitamin, and antioxidant enzyme status

Table 2 shows the serum levels of $\mathrm{Cu}, \mathrm{Zn}, \mathrm{Cu} / \mathrm{Zn} \mathrm{Se}$, vitamin $\mathrm{A}$, vitamin $\mathrm{E}$, vitamin $\mathrm{D}_{3}$, TAC, and $\mathrm{SOD}$ based on COVID-19 severity. Out of 155 patients, 5 (3.2\%), 38 (24.5\%), and 46 (29.7\%) had Cu, Zn, and Se levels below the lower KFSH\&RC reference limits of $0.701 \mu \mathrm{g} / \mathrm{mL}, \quad 0.693 \mu \mathrm{g} / \mathrm{mL}$, and $70.08 \mu \mathrm{g} / \mathrm{L}$, respectively. Two patients had the three metals below the reference limits. Forty-four (28.4\%), 17 (11\%), and four $(2.6 \%)$ patients had $\mathrm{Cu}, \mathrm{Zn}$ and Se levels above the upper reference limits of $1.401 \mu \mathrm{g} / \mathrm{mL}$, $1.242 \mu \mathrm{g} / \mathrm{mL}$, and $119.69 \mu \mathrm{g} / \mathrm{L}$, respectively. There were $27(17.4 \%)$ patients with $\mathrm{Cu} / \mathrm{Zn}$ ratios less than 1 . Among the patients, 50 (36.5\%), 14 (10.2\%), and 103 (68.2\%) had vitamin $\mathrm{A}, \mathrm{E}$, and $\mathrm{D}_{3}$ levels below the KFSH\&RC lower reference limits of $0.343 \mathrm{mg} / \mathrm{L}$, 





$5.5 \mathrm{mg} / \mathrm{L}$, and $30.05 \mu \mathrm{g} / \mathrm{L}$, respectively. However, there were 20 (14.6\%), 49 (35.8\%), and 23 (15.2\%) patients who had vitamin $\mathrm{A}, \mathrm{E}$, and $\mathrm{D}_{3}$ levels higher than the upper reference limits of $0.838 \mathrm{mg} / \mathrm{L}$, $15.5 \mathrm{mg} / \mathrm{L}$, and $30.05 \mu \mathrm{g} / \mathrm{L}$, respectively.

Potential confounders/risk factors associated with the COVID-19 severity and tested analytes

Patients with severe symptoms had the highest levels of WBC $(p=0.008)$, NEUT $(p<0.001)$, CRP $(p<0.001)$, and FER $(p=0.006)$. Additionally, these patients were older $(p=0.005)$ and had longer hospitalizations $(p<0.001)$. In contrast, patients with severe symptoms had the lowest levels of LYM and MONO ( $p<0.001$, for both). Patients with severe symptoms had the highest NLR and NMR $(p<0.001)$. No significant differences in LMR were obtained among the four groups $(p=0.209)$. Results are displayed in Table 3.

Bivariate analyses showed that only TAC was positively and significantly correlated with age $(p<0.001)$ and length of hospital stay $(p=0.002)$. Females had significantly higher $\mathrm{Cu}(p=0.034)$ but lower TAC $(r=0.011)$ than males. Patients with cancer had significantly lower $\mathrm{Se}$ and vitamin $\mathrm{D}_{3}$ levels $(p<0.01)$. Low vitamin $\mathrm{E}$ and vitamin $\mathrm{D}_{3}$ levels were obtained in patients who underwent organ transplants ( $p=0.003$ and $p=0.006$, respectively). Patients taking supplements had significantly higher vitamin E levels $(p=0.046)$ but lower SOD $(p=0.071)$. While WBC was negatively associated with $\mathrm{Cu} / \mathrm{Zn}$, it was positively associated with TAC. NEUT was negatively associated with $\mathrm{Zn}$ and Se but positively associated with TAC.

In contrast, LYM was positively correlated with $\mathrm{Zn}$, $\mathrm{Cu} / \mathrm{Zn}$, and Se but negatively correlated with TAC. An inverse relationship was obtained between MONO and $\mathrm{Cu} / \mathrm{Zn}$ and TAC. While CRP was positively correlated with $\mathrm{Cu}$, it was inversely associated with $\mathrm{Zn}$, Se, and vitamin A. FER was only associated with TAC. NLR was inversely correlated with $\mathrm{Zn}$ and TAC but positively correlated with $\mathrm{Cu} / \mathrm{Zn}$. Only TAC was positively correlated with NMR, and LMR was positively correlated with $\mathrm{Zn}$ and Se but negatively correlated with TAC. The results are presented in Table 4.
Relationship between tested analytes and severity of COVID-19

We used separate linear regression models to evaluate the unadjusted (crude) and adjusted relationships between each analyte and COVID-19 severity in the four groups of patients. All models were adjusted for age and medical history that were significantly associated with COVID-19 severity and confounders significantly related with the analyte, including laboratory and inflammation markers in the bivariate analyses at $p<0.1$. Table 5 shows that models adjusted for confounders but not for laboratory parameters showed a decrease in $\operatorname{Se}(\beta=-0.203$, $95 \% \mathrm{CI}-0.308,-0.015, p=0.074)$ in patients with severe COVID-19 symptoms compared to asymptomatic ones. Additionally, we observed a significant decrease in the regression estimates of vitamin $A$ in COVID-19 patients with severe $(\beta=-0.263,95 \%$ CI $-0.973,-0.034, p=0.036)$ and mild symptoms $(\beta=-0.262,95 \% \mathrm{CI}-0.78,0.023, p=0.064)$.

Further adjustment of regression models was performed separately for only laboratory parameters and inflammatory markers that were significantly associated with the analyte to examine whether they were independently related to disease severity. Table 5 shows that only $\mathrm{Cu}, \mathrm{Cu} / \mathrm{Zn}$, and Se had significant associations with COVID-19 severity.

In the $\mathrm{Cu}$ model, we obtained a significant increase in the regression estimates in patients with mild $(\beta=0.427,95 \%$ CI $0.04,0.467, p=0.021)$ and moderate $(\beta=0.402, \quad 95 \% \quad$ CI $0.006, \quad 0.42$, $p=0.044)$ COVID-19 in comparison to asymptomatic patients.

When we included LYM, MONO, or NLR in the $\mathrm{Cu} / \mathrm{Zn}$ model, we obtained a significant increase in the regression estimate in patients with mild symptoms $(\beta=0.373, \quad 95 \%$ CI $0.076,0.731, p=0.016)$, $(\beta=0.369,95 \%$ CI $0.066,0.732, p=0.019)$ and $(\beta=0.371,95 \%$ CI $0.074,0.729, p=0.017)$, respectively. Even though the pattern was the same in patients with moderate symptoms, the statistical significance was marginal after including LYM $(\beta=0.293,95 \%$ CI $-0.032,0.626, p=0.076)$, MONO $(\beta=0.309, \quad 95 \% \quad$ CI $-0.015, \quad 0.642$, $p=0.061)$ or NLR $(\beta=0.303,95 \%$ CI -0.021 , $0.634, p=0.061)$.

When incorporating CRP in the Se model, we observed a significant decrease in the regression 


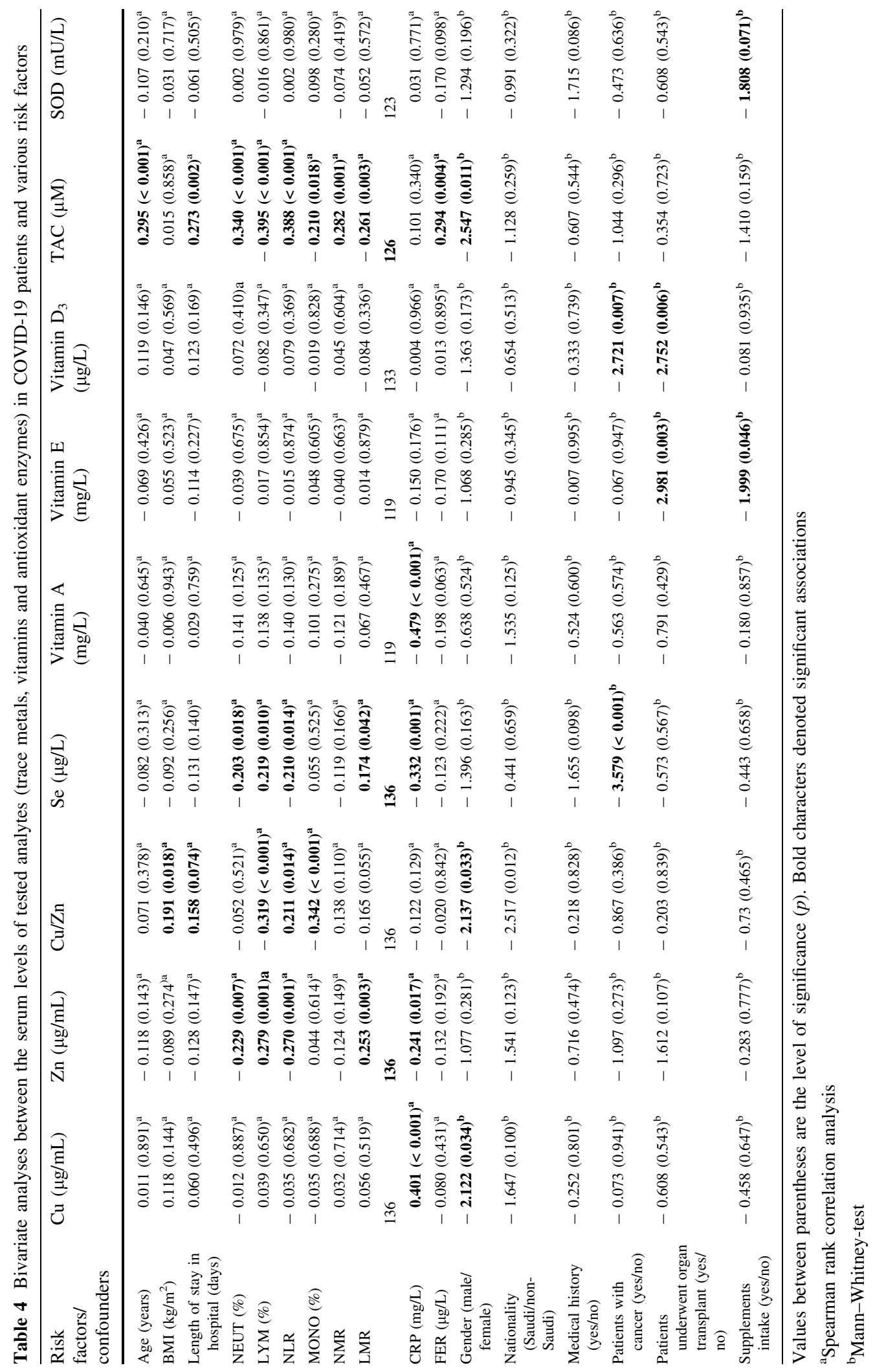




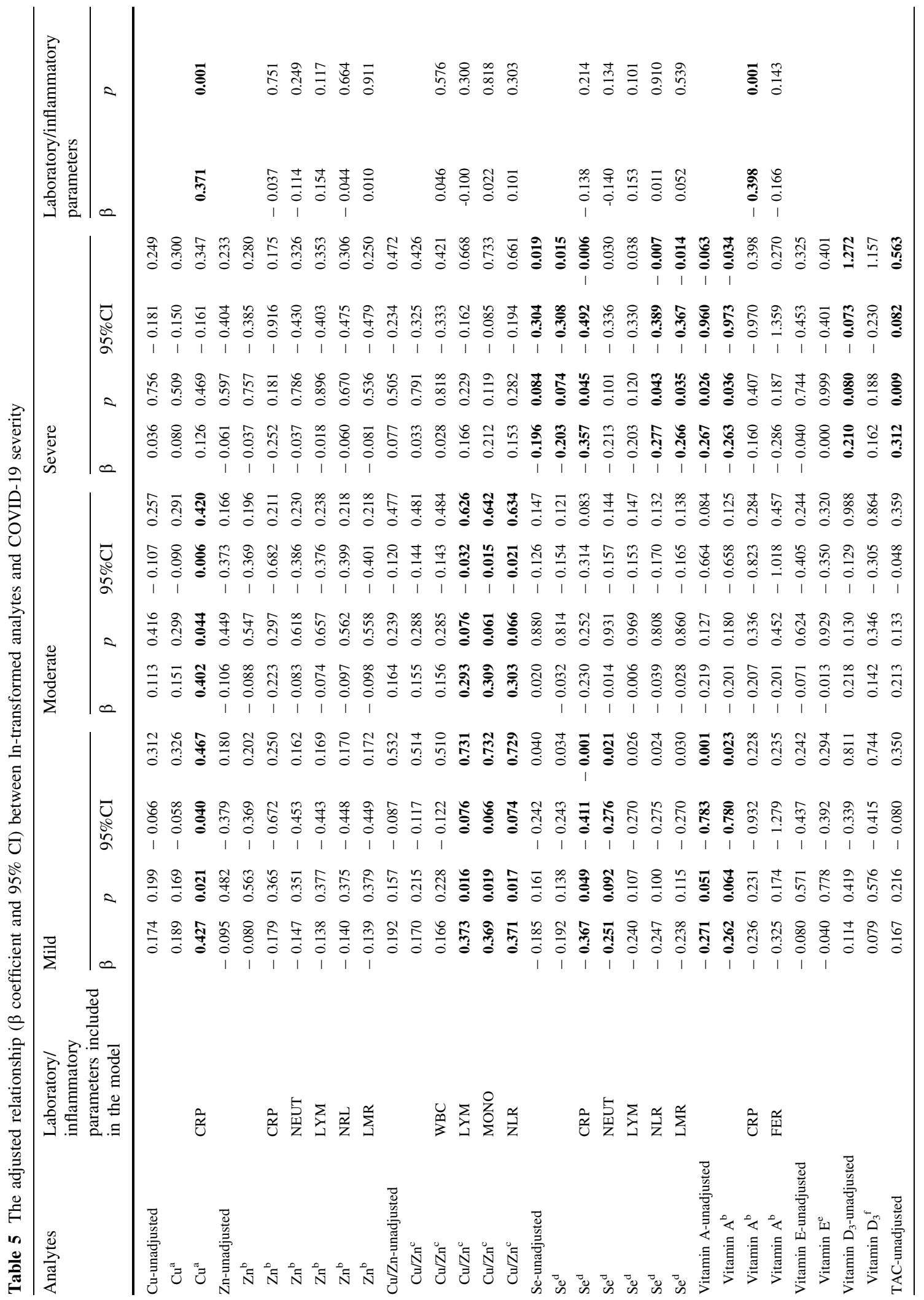







estimates of patients with mild symptoms ( $\beta-0.367$, $95 \%$ CI $-0.411,-0.001, p=0.049)$ and severe symptoms $(\beta=-0.357,95 \%$ CI $-0.492,-0.006$, $p=0.045)$. When incorporating NEUT in the Se model, we observed a decrease in the regression estimate of patients with mild symptoms $(\beta=--0.251, \quad 95 \% \quad$ CI $-0.276, \quad-0.021$; $p=0.092$ ). Again the regression estimate decreased in patients with severe symptoms when incorporating NLR $(\beta=-0.277,95 \%$ CI $-0.389,-0.007$, $p=0.043)$ or LMR $(\beta=-0.266,95 \%$ CI -0.367 , $-0.014, p=0.035)$ in the model.

However, the significant decrease in vitamin A observed in patients with severe or mild symptoms in crude and adjusted analyses for risk factors disappeared.

There were no changes in the relationship between COVID-19 severity and levels of $\mathrm{Zn}$, vitamin $\mathrm{E}$, vitamin $\mathrm{D}_{3}$, TAC, and SOD after adjusting the model for laboratory parameters or inflammatory markers. However, NEUT, LYM, and MONO remained significantly associated with TAC levels with $p$-values of $0.003,0.002$, and 0.017 , respectively, and marginally significant with FER $(p=0.083)$.

While the relationship between CRP and Se levels became non-significant $(p=0.214)$, it remained significant with $\mathrm{Cu}$ and vitamin A (both $p=0.001$ ) after adjusting the model.

\section{Discussion}

Our study revealed that a decline in serum Se levels was independently associated with COVID-19 severity. An increase in $\mathrm{Cu}$ and $\mathrm{Cu} / \mathrm{Zn}$ levels was associated with disease severity only after adjusting for specific individual laboratory parameters or inflammatory markers, suggesting their possible role in exacerbating inflammation in COVID-19 patients and might be synergistically associated with disease severity. A decrease in vitamin A was observed in patients with severe symptoms, which disappeared after adjusting for inflammatory markers. This result may highlight the potential role of inflammation in mediating the relationship between COVID-19 severity and vitamin A levels. Despite our patients' low status of $\mathrm{Zn}$, vitamin $\mathrm{D}_{3}$, and antioxidant enzyme (SOD), there is no evidence of their role in COVID-19 progression. Our findings reinforce that deficiency or excess of certain micronutrients plays an essential role in the pathogenesis of COVID-19. More studies are required to support our findings.

Several studies have shown that micronutrients play vital roles in maintaining tissue function, and their excess or deficiency can disturb metabolic functions that the immune system relies on to defend the body against infections (Pecora et al. 2020; Maggini et al. 2018). In this study, we assessed the levels of trace elements, vitamins, and antioxidant enzyme activity in four groups of COVID-19 patients and explored their associations with disease severity.

Trace elements ( $\mathrm{Se}, \mathrm{Cu}$, and $\mathrm{Zn}$ )

Se levels were low in approximately $30 \%$ of patients, followed by $\mathrm{Zn}(\sim 25 \%)$ and $\mathrm{Cu}(3 \%)$. Lower levels of these metals have been observed in patients diagnosed with various infectious diseases (Skalny et al. 2021; Weiss and Carver 2018; Oh et al. 2019; Sepehri et al. 2017). Se is an essential trace element in humans that supports antioxidant defense systems (Burk 2002) and, consequently, plays a role in immune-related diseases (Huang et al. 2012; Hoffmann and Berry 2008). Studies have shown that Se deficiency during influenza aggravates viral infections (Beck et al. 2001; Nelson et al. 2001). In our study, $30 \%$ of COVID-19 patients were Se deficient $(<70.08 \mu \mathrm{g} / \mathrm{L}$; mean value: $59.46 \mu \mathrm{g} / \mathrm{L})$. Our study showed that patients with severe COVID-19 had an $18 \%$ decrease in Se levels after adjusting for risk factors. However, the decline increased to $30 \%, 24 \%$, and $23 \%$ when CRP, NLR, and LMR, respectively, were separately included in the model. CRP, NLR, and LMR are inflammatory markers that correlate well with the progression of COVID-19 and/or other diseases (Danwang et al. 2020; Man et al. 2021). In our study, low CRP and NLR and high LMR were associated with elevated Se levels, which is indicative of the anti-inflammatory role of Se, particularly in viral infections (Guillin et al. 2019; Huang et al. 2012). Nonetheless, these relationships disappeared after adjusting the model for these inflammatory markers suggesting that $\mathrm{Se}$ is independently associated with COVID-19 severity, regardless of inflammation is a confounder or a result of Se deficiency. Both Majeed et al. (2021) and Skalny et al. (2021) found low Se levels in COVID-19 patients. Skalny et al (2021) reported that low Se levels were associated with lung 
damage in COVID-19 patients. Moghaddam et al. (2020) concluded that Se levels were significantly lower in COVID-19 non-survivors $(40.8 \mu \mathrm{g} / \mathrm{L})$ than in survivors $(53.3 \mu \mathrm{g} / \mathrm{L})$. In our study, Se levels were lower in 16 deceased patients $(75.41 \mu \mathrm{g} / \mathrm{L})$ than in 139 survivors $(83.84 \mu \mathrm{g} / \mathrm{L})$, statistically, not significant ( $p=0.106$ ), which might be related to the small sample size of deceased patients. Se levels in survivors were similar to the Se levels $(77.8 \mu \mathrm{g} / \mathrm{L})$ reported by Younesian et al. (2021). Se deficiency might be a risk factor for COVID-19 mortality (Bae and Kim 2020). In China, Zhang et al. (2020) found an association between COVID-19 cure rates and regional Se status. Studies have shown an association between COVID19 cure rates and regional Se status, suggesting an additional risk factor that might affect the human response to SARS-CoV-2 infections, particularly in populations where Se intake is sub-optimal or low (Bermano et al. 2021).

Both $\mathrm{Zn}$ and $\mathrm{Cu}$ are essential trace metals required for the appropriate function of the immune system, and nutritional deficiency of either mineral increases susceptibility to bacterial/viral infections (Wessels et al. 2017; Djoko et al. 2015). The antiviral properties of $\mathrm{Zn}$ have been investigated with coronaviruses, hepatitis C virus, and HIV (Barocas et al. 2019; Read et al. 2019). Researchers recommend $\mathrm{Zn}$ with antiviral medications to manage COVID-19 (Asl et al. 2021). While only $3 \%$ of our COVID-19 patients had $\mathrm{Cu}$ deficiency $(<0.18 \mu \mathrm{g} / \mathrm{mL})$, a higher percentage of patients $(25 \%)$ were $\mathrm{Zn}$ deficient $(<0.693 \mu \mathrm{g} / \mathrm{mL})$. Despite the high percentage of patients with $\mathrm{Zn}$ deficiency, we found no association with COVID-19 severity, even after adjusting for inflammatory markers (CRP, NRL, or LMR) or individual laboratory parameters (NEUT or LYM). Vogel-González et al. (2021) observed poor COVID-19 outcomes, such as worse clinical presentation, longer time to reach stability, and higher mortality rates with serum $\mathrm{Zn}$ levels $<0.5 \mu \mathrm{g} / \mathrm{mL}$ ( $23 \%$ of patients). In comparison, only seven patients with $\mathrm{Zn}$ levels $<0.5 \mu \mathrm{g} / \mathrm{mL}$, three of them with severe symptoms, were included in our study. A study by Gonçalves et al. (2021) showed that among $80 \%$ of patients who were $\mathrm{Zn}$ deficient $(<0.7 \mu \mathrm{g} / \mathrm{mL})$, there was an association with the severity of respiratory distress. The lack of an association in our study was related to the low prevalence of patients with low $\mathrm{Zn}$. The mean $\mathrm{Zn}$ value in our deficient patients was $0.584 \mu \mathrm{g} / \mathrm{mL}$, lower than the value $(0.745 \mu \mathrm{g} / \mathrm{mL})$ reported by Jothimani et al. (2020) in patients who developed complications associated with a prolonged hospital stay and increased mortality. Serum Zn levels was lower in deceased COVID-19 patients $(0.7 \mu \mathrm{g} / \mathrm{mL})$ than in survivors $(1.117 \mu \mathrm{g} / \mathrm{mL})$ but with borderline significance $(p=0.065)$.

Data on serum Cu status in COVID-19 patients are limited, apart from hypothesizing that $\mathrm{Cu}$ potent antiviral activities may act as a preventive and therapeutic approach against COVID-19 by boosting innate and adaptive immunity (Raha et al. 2020). In line with Skalny et al. (2021) and Zeng et al. (2021a), the levels of $\mathrm{Cu}$ in serum were elevated $(>1.401 \mu \mathrm{g} /$ $\mathrm{mL}$ ) in $28 \%$ of our COVID-19 patients. In the present study, the positive association between $\mathrm{Cu}$ and CRP affected the relationship between $\mathrm{Cu}$ and COVID-19 severity. Patients with mild and moderate COVID-19 symptoms had a 50\% and 53\%, respectively, increase in $\mathrm{Cu}$ levels compared to asymptomatic patients. This association was observed only after controlling for CRP; however, the marker remained significantly and independently associated with $\mathrm{Cu}$ levels. This result may indicate the possible participation of $\mathrm{Cu}$ in inflammatory and pro-oxidant mechanisms in the pathogenesis of COVID-19 (Fernandes et al. 2020; Bo et al. 2008). Even though $\mathrm{Cu}$ is an essential micronutrient involved in various biological mechanisms, controlling its homeostasis is critical in maintaining the balance between absorption and distribution and biliary/urinary excretion (de Romaña et al. 2011; Peña et al. 1999). Both Cu deficiency and excess have been associated with specific clinical symptoms (Hordyjewska et al. 2014).

In our study, we noted an imbalance in the levels of $\mathrm{Cu}$ and $\mathrm{Zn}$, which has been reported in inflammatory conditions. The normal ratio of $\mathrm{Cu}$ to $\mathrm{Zn}$ in adults is close to 1:1 (Malavolta et al. 2015). The $\mathrm{Cu} / \mathrm{Zn}$ ratio in the current study was high $(1.5 \pm 0.63)$, with 128 ( $\sim 83 \%$ ) patients having a ratio above 1 , which is an indicator of inflammation. The ratio was significantly correlated with CRP $(r=0.44, p<0.001)$. It has been reported that $\mathrm{Cu} / \mathrm{Zn}>2$ means severe bacterial infection (Bahi et al. 2017). There were 33 (21\%) patients in our study with $\mathrm{Cu} / \mathrm{Zn}$ ratio $>2$. Skalny et al. (2021), who observed elevated $\mathrm{Cu} / \mathrm{Zn}$ ratios in COVID-19 patients, reported that the ratio increased gradually with disease severity. $\mathrm{Cu} / \mathrm{Zn}$ increased up to $45 \%$ in patients with mild symptoms and $34 \%-36 \%$ in 
patients with moderate symptoms compared to asymptomatic patients. These relationships were only observed when one of the laboratory parameters (LYM or MONO) or inflammatory marker (NLR) was included in the regression model. Furthermore, none of these inflammatory markers remained significantly associated with $\mathrm{Cu} / \mathrm{Zn}$ after adjusting the model. These findings suggest that $\mathrm{Cu} / \mathrm{Zn}$ might further exacerbate inflammation in COVID-19 patients and be synergistically associated with disease severity.

\section{Vitamins $\left(D_{3}, A\right.$, and $\left.E\right)$}

Vitamin $\mathrm{D}_{3}$ deficiency was observed in $68 \%$ of our patients. In general, the prevalence of vitamin D deficiency among Saudis is high ( 64\%) (Al-Alyani et al. 2018). Increasing evidence shows the relationship between vitamin D deficiency and a high risk of infectious diseases (Watkins et al. 2015) due to its immunomodulatory action in human respiratory epithelial cells infected with respiratory viruses (Greiller and Martineau 2015; Skrobot et al. 2018). The clinical connection between low vitamin D status and viral infections has prompted researchers to explore its potential link with SARS-CoV-2 infection severity and/or mortality (Peng et al. 2021; Charoenngam et al. 2021). In our study, even though asymptomatic patients had the lowest vitamin $\mathrm{D}_{3}$ levels $(10.9 \mu \mathrm{g} / \mathrm{L})$ in comparison to those with mild $(14.2 \mu \mathrm{g} / \mathrm{L})$, moderate $(15.0 \mu \mathrm{g} / \mathrm{L})$, and severe symptoms $(19.9 \mu \mathrm{g} / \mathrm{L})$, there were no significant differences among patients with different symptoms because all were vitamin D deficient $(<20.05 \mu \mathrm{g} / \mathrm{L})$. The concept of using vitamin $\mathrm{D}$ to prevent or reduce the risk of COVID-19 infection or as an intervention strategy has been emphasized in the literature (Shah et al. 2021; Brenner 2021). Despite the evidence, other studies found that vitamin D sufficiency does not lower the risk of adverse clinical outcomes in COVID-19, such as duration of hospitalization and disease severity, and more research is required to support the potential benefits of vitamin D supplementation (Davoudi et al. 2021; Jolliffe et al. 2021; Grove et al. 2021; Hastie et al. 2020; Brandão et al. 2021). According to Brandão et al. (2021), susceptibility to SARS-CoV-2 infections might be related to several clinical, environmental, socioeconomic, and cultural factors rather than vitamin D status. Hastie et al. (2020) reported that assessing vitamin $\mathrm{D}_{3}$ status would not be useful in clinical practice. AlSafar et al. (2021) showed that higher risks of COVID-19 and death were associated with vitamin $D_{3}$ levels $<12 \mu \mathrm{g} / \mathrm{L}$. In our study, 80 patients had vitamin $\mathrm{D}_{3}$ levels $<12 \mu \mathrm{g} / \mathrm{L}: \quad 1 / 16$ (asymptomatic), 27/47 (mild), 33/67 (moderate), and 10/21 (severe). Even though 12 out of the 16 deceased patients had vitamin $\mathrm{D}_{3}$ levels $<12 \mu \mathrm{g} / \mathrm{L}$ with a mean value of $5.09 \mu \mathrm{g} / \mathrm{L}$, there were no significant differences with the vitamin $\mathrm{D}_{3}$ levels in survivors $(4.81 \mu \mathrm{g} /$ L). In contrast, $15 \%$ of our patients had serum vitamin $\mathrm{D}_{3}$ levels $>30 \mu \mathrm{g} / \mathrm{L}$ with a mean value of $40.12 \mu \mathrm{g} / \mathrm{L}$ (30.96-71.62 $\mu \mathrm{g} / \mathrm{L}): \quad 1 / 16$ (asymptomatic), 7/47 (mild), 11/67 (moderate), and 4/21 (severe). Four of our patients had vitamin $\mathrm{D}_{3}$ levels $>50 \mu \mathrm{g} / \mathrm{L}$, two of which had severe COVID-19 symptoms who did not take vitamin D supplements. In contrast, the other two had mild and moderate symptoms, and both were taking vitamin D supplements. Vitamin D overdose may lead to hypercalcemia due to hypervitaminosis D (Marcinowska-Suchowierska et al. 2018).

Vitamin A is another micronutrient that plays a vital role in innate and acquired immunity and the body's response to inflammation (Rubin et al. 2017). Its deficiency has been associated with a high risk of infection (Huang et al. 2018; Mawson 2013). Due to its immunomodulatory properties, researchers recommend vitamin A as a potential adjuvant in COVID-19 therapy (Trasino 2020; Gaziano et al. 2021). To the best of our knowledge, there are no studies assessing vitamin A status in COVID-19 patients. In our study, $37 \%$ of our patients were vitamin A deficient $(<0.343 \mathrm{mg} / \mathrm{L})$. During infection, vitamin $\mathrm{A}$ is depleted, suppressing its levels in serum, particularly in COVID-19, which as a result, the immune defense mechanism switches from the congenital immune system to the adaptive immune system, where retinoic acids cannot be used (Sarohan 2020). We observed that patients with severe COVID-19 symptoms had a $23 \%$ decrease in vitamin A levels compared to asymptomatic patients, which disappeared after controlling for CRP or FER. CRP remained significantly and independently associated with vitamin A. It is possible that systemic inflammation could have mediated the relationship between vitamin $\mathrm{A}$ and disease severity. Barffour et al. (2019) and Maqsood et al. (2004) reported increased serum CRP levels in patients with viral infections and vitamin A deficiency. A study by Larson et al. (2018) recommended 
adjusting for inflammation to avoid overestimating vitamin deficiency, particularly during the acute phase of infection (Mitra et al. 1998). Low levels of vitamin $\mathrm{A}$ in serum have been associated with liver damage, which is a clinical COVID-19 feature (Herta and Berg 2021). A study showed that patients with cirrhosis had serum vitamin A levels of $0.166 \mathrm{mg} / \mathrm{L}$, while controls had serum vitamin A levels of $0.259 \mathrm{mg} / \mathrm{L}$ (Ukleja et al. 2002). Twelve of our patients had levels below $0.166 \mathrm{mg} / \mathrm{L}(0.074-0.162 \mathrm{mg} / \mathrm{L})$. In contrast, high levels of vitamin A in serum $(>0.839 \mathrm{mg} / \mathrm{L})$ were obtained in $15 \%$ of patients, with the majority of patients being asymptomatic (5/15). Mawson et al. (2021) proposed that liver damage due to SARS-CoV2 leads to the release of retinoic acid and stored retinyl esters into the circulation that cause further damage to organs including the lungs, heart, blood vessels, and skin.

Vitamin $\mathrm{E}$ is another micronutrient that modulates immune and inflammatory responses leading to improved protection against infection and other immune-related diseases (Wu and Meydani 2019; Tang and Smit 1998). Though no study has evaluated the association between vitamin E and COVID-19, it has been hypothesized that the vitamin can amplify the immune system due to its antioxidant properties and its roles in maintaining the integrity of the T-cell membranes and reducing the duration of infection (BourBour et al. 2020). In our study, 10\% of COVID19 patients had vitamin $\mathrm{E}<5.5 \mathrm{mg} / \mathrm{L}$, and the levels were not significantly different among the four groups of patients. Surprisingly, $36 \%$ of our patients had vitamin E levels $>15.5 \mathrm{mg} / \mathrm{L}(15.6-111.77 \mathrm{mg} / \mathrm{L})$ : 8/15 (asymptomatic), 17/41 (mild), 18/62 (moderate), and $6 / 19$ (severe). Elevated vitamin E levels were attributed to supplementation in $73 \%$ of patients. Studies have shown that high vitamin $\mathrm{E}$ intake might be associated with decreased levels of vitamin K-induced coagulation factors (Booth et al. 2004; Owen and Dewald 2021). A study found that patients with intracranial hemorrhages and who took vitamin $\mathrm{E}$ supplementation had vitamin E levels in serum that ranged between 23.3 and $46.7 \mathrm{mg} / \mathrm{L}$ (Le et al. 2020). In our study, 16 patients had vitamin $\mathrm{E}>23.3 \mathrm{mg} / \mathrm{L}$, and three of the deceased patients had the highest vitamin E levels $(111.77 \mathrm{mg} / \mathrm{L})$. Thirteen out of these patients with high vitamin $\mathrm{E}$ were taking supplements.

Our results suggest that the link between supplements intake and a patient's health conditions is underestimated and under-reported. It needs to be assessed to avoid overdosing, which might be behind the etiology of health conditions or the exacerbatation of existing conditions.

\section{Antioxidant enzyme activity}

Oxidative stress, which results from an imbalance between reactive oxygen species (ROS) and enzymatic and nonenzymatic antioxidants, plays a complex role in the pathogenesis of human diseases (Ďuračková 2010). A wide range of viral and bacterial infections trigger oxidative stress (Ivanov et al. 2017). Inflammation due to SARS-CoV-2 infection and oxidative stress plays roles in COVID-19 progression and response to therapy (Forcados et al. 2021; BeltránGarcía et al. 2020). We evaluated the role of oxidative stress in the pathogenesis of COVID-19 by assessing the levels of SOD, which is an enzymatic antioxidant, and TAC, which represents the cumulative effect of all antioxidants present in serum rather than a single antioxidant (Ghiselli et al. 2000), that limit its benefits (Rubio et al. 2016). Among all four COVID-19 groups, there were no significant differences in TAC and SOD levels, even when laboratory and inflammatory markers were included in the model. An increase in NEUT and a decrease in LYM and MONO were independently associated with TAC levels. These parameters are predictors of inflammation, particularly in infection (Wu et al. 2021), and their association, particularly NEUT, with ROS generation has been documented (Banerjee et al. 2012). In a recent review, Goud et al. (2021) hypothesized that NEUT, eosinophils, MONO, macrophages, mitochondrial damage, and NADPH oxidase are the major sources of ROS generation at sites of inflammation. The authors emphasized that ROS contribute to the pathogenesis of COVID-19. Gadotti et al. (2021) were unable to confirm the interplay between COVID-19 severity and oxidative stress in patients with severe COVID-19. However, the lowest TAC values were found in asymptomatic patients $(979.2 \mu \mathrm{M})$ and the highest in patients with severe COVID-19 symptoms $(1326.1 \mu \mathrm{M})$, with a significant difference between the two $(p=0.009)$ based on bivariate analysis. In contrast to the results reported by Karkhanei et al. (2021), we observed that TAC levels and length of hospital stay were associated ( $r=0.273, p=0.002$ ). Additionally, deceased patients had higher TAC levels 
than survivors $(p=0.047)$. The low SOD activity in our patients reflects an increase in ROS production associated with SARS-CoV-2 infection (Wenzhong and Hualan 2021; Barciszewska 2021). Similar results were reported by Muhammad et al. (2021). The information in the literature on the antioxidant status in COVID-19 patients is both limited and conflicted.

In general, our findings showed that inflammation could be triggered by excess or deficiency of certain trace metals and vitamins. When their predictive role in COVID-19 severity is investigated, it is essential to adjust the regression model for inflammatory markers.

The present study had some limitations. First, the small sample size may have some impact on the statistical power. Second, the study recruited patients from a single hospital with multiple co-morbidities, which likely had adverse effects on the progression of COVID-19. Third, there were no data on healthy patients because the samples were collected during the highest peak of the pandemic when subject recruitment was difficult. Fourth, deficiencies in some micronutrients could be due to various chronic health conditions and/or behavioral factors that increase COVID-19 risk. Fifth, there were incomplete data for some patients because we used the remaining serum samples that were withdrawn to monitor the patients. Furthermore, we did not include immunological markers because they were performed after admission and not in all cases. Six, the laboratory parameters were limited during the hospital routine assessment. Seven, we did not measure levels of lipids, which are reliable indicators of vitamin E status (Winbauer et al. 1999). Finally, some confounding factors, such as socioeconomic, that might impact COVID-19 severity were not evaluated (Hawkins et al. 2020).

Despite these limitations, the data were reliable and homogenous because they were extracted from a centralized database where all patients were tested and treated under the same guidelines. Furthermore, our data provide valuable information on the role of micronutrients and antioxidant deficiency in the pathogenesis of COVID-19.

\section{Conclusions}

Our study findings showed a 18\% decrease in Se levels in patients with severe symptoms, which increased to
$30 \%$ after adjusting the model for inflammatory markers. Regardless of inflammation, Se was independently associated with COVID-19 severity. In contrast, a $50 \%$ increase in $\mathrm{Cu}$ was associated with disease severity only after adjusting for CRP, reflecting its possible inflammatory and pro-oxidant role in COVID-19 pathogenesis. We noted an imbalance in the ratio between $\mathrm{Cu}$ and $\mathrm{Zn}$, with $\sim 83 \%$ of patients having a $\mathrm{Cu}$-to- $\mathrm{Zn}$ ratio $>1$, which is an indicator of inflammation. $\mathrm{Cu}$-to-Zn ratio increased to $45 \%$ in patients with mild symptoms and to $34 \%-36 \%$ in patients with moderate symptoms when compared to asymptomatic patients. These relationships were only obtained when one of the laboratory parameters (lymphocyte or monocyte) or inflammatory markers (neutrophil-to-lymphocyte ratio) was included in the regression model. These findings suggest that $\mathrm{Cu} / \mathrm{Zn}$ might further exacerbate inflammation in COVID-19 patients and might be synergistically associated with disease severity. Even though a $23 \%$ decrease in vitamin A was observed in patients with severe symptoms, it disappeared after adjusting for inflammatory markers. This result highlights the potential role of inflammation in mediating the relationship between COVID-19 severity and vitamin A levels. Despite our patients' low status of $\mathrm{Zn}$, vitamin $\mathrm{D}_{3}$, and antioxidant enzyme (SOD), there is no evidence of their role in COVID-19 progression. Our findings reinforce that the deficiency or excess of certain micronutrients plays an essential role in the pathogenesis of COVID-19. More studies are required to support our results.

Author contributions IAS- study design, data analysis, results interpretation and writing the manuscript. NA- collection of clinical data. HA- methodology/validation. REmethodology/validation. MS- sampling design. FA- samples provision. RB- methodology. MA- resources.

Funding This study received funding from King Faisal Specialist Hospital and Research Centre (RAC\# 2200025).

Data availability Not applicable.

\section{Declarations}

Conflict of interest The authors reported no potential conflict of interest. 


\section{References}

Al-Alyani H, Al-Turki HA, Al-Essa ON, Alani FM, Sadat-Ali M (2018) Vitamin D deficiency in Saudi Arabians: a reality or simply hype: a meta-analysis (2008-2015). J Family Community Med 25(1):1-4. https://doi.org/10.4103/jfcm. JFCM_73_17

AlSafar H, Grant WB, Hijazi R, Uddin M, Alkaabi N, Tay G et al (2021) COVID-19 disease severity and death in relation to vitamin D status among SARS-CoV-2-positive UAE residents. Nutrients. https://doi.org/10.3390/ nu13051714

Anurag A, Jha PK, Kumar A (2020) Differential white blood cell count in the COVID-19: a cross-sectional study of 148 patients. Diabet Metab Syndr 14(6):2099-2102. https://doi. org/10.1016/j.dsx.2020.10.029

Asl SH, Nikfarjam S, Majidi Zolbanin N, Nassiri R, Jafari R (2021) Immunopharmacological perspective on zinc in SARS-CoV-2 infection. Int Immunopharmacol 96:107630. https://doi.org/10.1016/j.intimp.2021.107630

Bae M, Kim H (2020) Mini-review on the roles of vitamin C, vitamin $\mathrm{D}$, and selenium in the immune system against COVID-19. Molecules. https://doi.org/10.3390/ molecules 25225346

Bahi GA, Boyvin L, Méité S, M'Boh GM, Yeo K, N'Guessan KR et al (2017) Assessments of serum copper and zinc concentration, and the $\mathrm{Cu} / \mathrm{Zn}$ ratio determination in patients with multidrug resistant pulmonary tuberculosis (MDR-TB) in Côte d'Ivoire. BMC Infect Dis 17(1):257. https://doi.org/10.1186/s12879-017-2343-7

Banerjee A, Mondal NK, Das D, Ray MR (2012) Neutrophilic inflammatory response and oxidative stress in premenopausal women chronically exposed to indoor air pollution from biomass burning. Inflammation 35(2):671-683. https://doi.org/10.1007/s10753-011-93602

Barciszewska AM (2021) Elucidating of oxidative distress in COVID-19 and methods of its prevention. Chem Biol Interact 344:109501. https://doi.org/10.1016/j.cbi.2021. 109501

Barffour MA, Schulze KJ, Kalungwana N, Moss WJ, West KP $\mathrm{Jr}$, Chileshe J et al (2019) Relative contributions of malaria, inflammation, and deficiencies of iron and vitamin A to the burden of anemia during low and high malaria seasons in rural zambian children. J Pediatr 213:74-81.e71. https:// doi.org/10.1016/j.jpeds.2019.06.039

Barocas JA, So-Armah K, Cheng DM, Lioznov D, Baum M, Gallagher K et al (2019) Zinc deficiency and advanced liver fibrosis among HIV and hepatitis C co-infected antiretroviral naïve persons with alcohol use in Russia. PLoS ONE 14(6):e0218852. https://doi.org/10.1371/journal. pone. 0218852

Beck MA, Nelson HK, Shi Q, Van Dael P, Schiffrin EJ, Blum S et al (2001) Selenium deficiency increases the pathology of an influenza virus infection. FASEB J 15(8):1481-1483

Beltrán-García J, Osca-Verdegal R, Pallardó FV, Ferreres J, Rodríguez M, Mulet S et al (2020) Oxidative stress and inflammation in COVID-19-associated sepsis: the potential role of anti-oxidant therapy in avoiding disease progression. Antioxidants. https://doi.org/10.3390/antiox9100936
Bermano G, Méplan C, Mercer DK, Hesketh JE (2021) Selenium and viral infection: are there lessons for COVID-19? $\mathrm{Br}$ J Nutr 125(6):618-627. https://doi.org/10.1017/ s0007114520003128

Bo S, Durazzo M, Gambino R, Berutti C, Milanesio N, Caropreso A et al (2008) Associations of dietary and serum copper with inflammation, oxidative stress, and metabolic variables in adults. J Nutr 138(2):305-310. https://doi.org/ 10.1093/jn/138.2.305

Booth SL, Golly I, Sacheck JM, Roubenoff R, Dallal GE, Hamada K et al (2004) Effect of vitamin E supplementation on vitamin $\mathrm{K}$ status in adults with normal coagulation status. Am J Clin Nutr 80(1):143-148. https://doi.org/10. 1093/ajcn/80.1.143

BourBour F, Mirzaei Dahka S, Gholamalizadeh M, Akbari ME, Shadnoush M, Haghighi M et al (2020) Nutrients in prevention, treatment, and management of viral infections; special focus on coronavirus. Arch Physiol Biochem. https://doi.org/10.1080/13813455.2020.1791188

Brandão C, Chiamolera MI, Biscolla RPM, Lima JVJ, De Francischi Ferrer CM, Prieto WH et al (2021) No association between vitamin D status and COVID-19 infection in São Paulo, Brazil. Arch Endocrinol Metab. https://doi.org/ 10.20945/2359-3997000000343

Brenner H (2021) Vitamin D supplementation to prevent COVID-19 infections and deaths-accumulating evidence from epidemiological and intervention studies calls for immediate action. Nutrients. https://doi.org/10.3390/ nu13020411

Burk RF (2002) Selenium, an antioxidant nutrient. Nutr Clin Care 5(2):75-79. https://doi.org/10.1046/j.1523-5408. 2002.00006.x

Campi I, Gennari L, Merlotti D, Mingiano C, Frosali A, Giovanelli L et al (2021) Vitamin D and COVID-19 severity and related mortality: a prospective study in Italy. BMC Infect Dis 21(1):566. https://doi.org/10.1186/s12879-02106281-7

Chan JF-W, Kok K-H, Zhu Z, Chu H, To KK-W, Yuan S et al (2020a) Genomic characterization of the 2019 novel human-pathogenic coronavirus isolated from a patient with atypical pneumonia after visiting Wuhan. Emerg Microbes Infect 9(1):221-236. https://doi.org/10.1080/22221751. 2020.1719902

Chan JF, Yuan S, Kok KH, To KK, Chu H, Yang J et al (2020b) A familial cluster of pneumonia associated with the 2019 novel coronavirus indicating person-to-person transmission: a study of a family cluster. Lancet 395(10223):514-523. https://doi.org/10.1016/s01406736(20)30154-9

Charoenngam N, Shirvani A, Holick MF (2021) Vitamin D and its potential benefit for the COVID-19 pandemic. Endocr Pract 27(5):484-493. https://doi.org/10.1016/j.eprac.2021. 03.006

Danwang C, Endomba FT, Nkeck JR, Wouna DLA, Robert A, Noubiap JJ (2020) A meta-analysis of potential biomarkers associated with severity of coronavirus disease 2019 (COVID-19). Biomark Res 8(1). https://doi.org/10.1186/ s40364-020-00217-0

Davoudi A, Najafi N, Aarabi M, Tayebi A, Nikaeen R, Izadyar H et al (2021) Lack of association between vitamin D insufficiency and clinical outcomes of patients with COVID-19 
infection. BMC Infect Dis 21(1):450. https://doi.org/10. 1186/s12879-021-06168-7

de Romaña DL, Olivares M, Uauy R, Araya M (2011) Risks and benefits of copper in light of new insights of copper homeostasis. J Trace Elem Med Biol 25(1):3-13. https:// doi.org/10.1016/j.jtemb.2010.11.004

Djoko KY, Ong CL, Walker MJ, McEwan AG (2015) The role of copper and zinc toxicity in innate immune defense against bacterial pathogens. $J$ Biol Chem 290(31):18954-18961. https://doi.org/10.1074/jbc.R115. 647099

Domingo JL, Marquès M (2021) The effects of some essential and toxic metals/metalloids in COVID-19: a review. Food Chem Toxicol 152:112161. https://doi.org/10.1016/j.fct. 2021.112161

Duračková Z (2010) Some current insights into oxidative stress. Physiol Res 59(4):459-469. https://doi.org/10.33549/ physiolres.931844

Fedele D, De Francesco A, Riso S, Collo A (2021) Obesity, malnutrition, and trace element deficiency in the coronavirus disease (COVID-19) pandemic: an overview. Nutrition 81:111016. https://doi.org/10.1016/j.nut.2020. 111016

Fernandes IG, de Brito CA, Dos Reis VMS, Sato MN, Pereira NZ (2020) SARS-CoV-2 and other respiratory viruses: what does oxidative stress have to do with it? Oxid Med Cell Longev 2020:8844280. https://doi.org/10.1155/2020/ 8844280

Forcados GE, Muhammad A, Oladipo OO, Makama S, Meseko CA (2021) Metabolic implications of oxidative stress and inflammatory process in SARS-CoV-2 pathogenesis: therapeutic potential of natural antioxidants. Front Cell Infect Microbiol 11:654813. https://doi.org/10.3389/ fcimb.2021.654813

Gadotti AC, Lipinski AL, Vasconcellos FT, Marqueze LF, Cunha EB, Campos AC et al (2021) Susceptibility of the patients infected with Sars-Cov2 to oxidative stress and possible interplay with severity of the disease. Free Radic Biol Med 165:184-190. https://doi.org/10.1016/j. freeradbiomed.2021.01.044

Gaziano R, Pistoia ES, Campione E, Fontana C, Marino D, Favaro M et al (2021) Immunomodulatory agents as potential therapeutic or preventive strategies for COVID19. Eur Rev Med Pharmacol Sci 25(11):4174-4184. https://doi.org/10.26355/eurrev_202106_26061

Ghiselli A, Serafini M, Natella F, Scaccini C (2000) Total antioxidant capacity as a tool to assess redox status: critical view and experimental data. Free Radic Biol Med 29(11):1106-1114. https://doi.org/10.1016/s08915849(00)00394-4

Gombart AF, Pierre A, Maggini S (2020) A review of micronutrients and the immune system-working in harmony to reduce the risk of infection. Nutrients. https://doi. org/10.3390/nu12010236

Gonçalves TJM, Gonçalves S, Guarnieri A, Risegato RC, Guimarães MP, de Freitas DC et al (2021) Association between low zinc levels and severity of acute respiratory distress syndrome by new coronavirus SARS-CoV-2. Nutr Clin Pract 36(1):186-191. https://doi.org/10.1002/ncp.10612

Goud PT, Bai D, Abu-Soud HM (2021) A multiple-hit hypothesis involving reactive oxygen species and myeloperoxidase explains clinical deterioration and fatality in COVID-19. Int J Biol Sci 17(1):62-72. https://doi. org/10.7150/ijbs.51811

Greiller CL, Martineau AR (2015) Modulation of the immune response to respiratory viruses by vitamin D. Nutrients 7(6):4240-4270. https://doi.org/10.3390/nu7064240

Grove A, Osokogu O, Al-Khudairy L, Mehrabian A, Zanganeh M, Brown A et al (2021) Association between vitamin D supplementation or serum vitamin D level and susceptibility to SARS-CoV-2 infection or COVID-19 including clinical course, morbidity and mortality outcomes? A systematic review. BMJ Open 11(5):e043737. https://doi. org/10.1136/bmjopen-2020-043737

Guan W-J, Ni Z-Y, Hu Y, Liang W-H, Ou C-Q, He J-X et al (2020) Clinical characteristics of coronavirus disease 2019 in china. $\mathrm{N}$ Engl $\mathrm{J}$ Med. https://doi.org/10.1056/ NEJMoa2002032

Guillin O, Vindry C, Ohlmann T, Chavatte L (2019) Selenium, selenoproteins and viral infection. Nutrients 11(9):2101. https://doi.org/10.3390/nu11092101

Hastie CE, Mackay DF, Ho F, Celis-Morales CA, Katikireddi SV, Niedzwiedz CL et al (2020) Vitamin D concentrations and COVID-19 infection in UK Biobank. Diabet Metab Syndr 14(4):561-565. https://doi.org/10.1016/j.dsx.2020. 04.050

Hawkins RB, Charles EJ, Mehaffey JH (2020) Socio-economic status and COVID-19-related cases and fatalities. Public Health 189:129-134. https://doi.org/10.1016/j.puhe.2020. 09.016

Henry BM, de Oliveira MHS, Benoit S, Plebani M, Lippi G (2020) Hematologic, biochemical and immune biomarker abnormalities associated with severe illness and mortality in coronavirus disease 2019 (COVID-19): a meta-analysis. Clin Chem Lab Med 58(7):1021-1028. https://doi.org/10. 1515/cclm-2020-0369

Herta T, Berg T (2021) COVID-19 and the liver-lessons learned. Liver Int 41(Suppl 1):1-8. https://doi.org/10.1111/ liv. 14854

Hoffmann PR, Berry MJ (2008) The influence of selenium on immune responses. Mol Nutr Food Res 52(11):1273-1280. https://doi.org/10.1002/mnfr.200700330

Hordyjewska A, Popiołek $€$, Kocot J (2014) The many "faces" of copper in medicine and treatment. Biometals 27(4):611-621. https://doi.org/10.1007/s10534-014-97365

Huang Z, Rose AH, Hoffmann PR (2012) The role of selenium in inflammation and immunity: from molecular mechanisms to therapeutic opportunities. Antioxid Redox Signal 16(7):705-743. https://doi.org/10.1089/ars.2011.4145

Huang Z, Liu Y, Qi G, Brand D, Zheng SG (2018) Role of vitamin $\mathrm{A}$ in the immune system. J Clin Med 7(9):258. https://doi.org/10.3390/jcm7090258

Ivanov AV, Bartosch B, Isaguliants MG (2017) Oxidative stress in infection and consequent disease. Oxid Med Cell Longev 2017:3496043. https://doi.org/10.1155/2017/ 3496043

Jolliffe DA, Camargo CA Jr, Sluyter JD, Aglipay M, Aloia JF, Ganmaa D et al (2021) Vitamin D supplementation to prevent acute respiratory infections: a systematic review and meta-analysis of aggregate data from randomised 
controlled trials. Lancet Diabet Endocrinol 9(5):276-292. https://doi.org/10.1016/s2213-8587(21)00051-6

Jothimani D, Kailasam E, Danielraj S, Nallathambi B, Ramachandran H, Sekar P et al (2020) COVID-19: poor outcomes in patients with zinc deficiency. Int J Infect Dis 100:343-349. https://doi.org/10.1016/j.ijid.2020.09.014

Karkhanei B, Talebi Ghane E, Mehri F (2021) Evaluation of oxidative stress level: total antioxidant capacity, total oxidant status and glutathione activity in patients with COVID-19. New Microbes New Infect 42:100897. https:// doi.org/10.1016/j.nmni.2021.100897

Khatiwada S, Subedi A (2021) A mechanistic link between selenium and coronavirus disease 2019 (COVID-19). Curr Nutr Rep 10(2):125-136. https://doi.org/10.1007/s13668021-00354-4

Larson LM, Guo J, Williams AM, Young MF, Ismaily S, Addo OY et al (2018) Approaches to assess vitamin a status in settings of inflammation: biomarkers reflecting inflammation and nutritional determinants of anemia (BRINDA) project. Nutrients. https://doi.org/10.3390/nu10081100

Le NK, Kesayan T, Chang JY, Rose DZ (2020) Cryptogenic intracranial hemorrhagic strokes associated with hypervitaminosis E and acutely elevated $\alpha$-tocopherol levels. J Stroke Cerebrovasc Dis 29(5):104747. https://doi.org/10. 1016/j.jstrokecerebrovasdis.2020.104747

Li G, Fan Y, Lai Y, Han T, Li Z, Zhou P et al (2020a) Coronavirus infections and immune responses. J Med Virol 92(4):424-432. https://doi.org/10.1002/jmv.25685

Li X, Geng M, Peng Y, Meng L, Lu S (2020b) Molecular immune pathogenesis and diagnosis of COVID-19. J Pharm Anal. https://doi.org/10.1016/j.jpha.2020.03.001

Maggini S, Pierre A, Calder PC (2018) Immune function and micronutrient requirements change over the life course. Nutrients. https://doi.org/10.3390/nu10101531

Majeed M, Nagabhushanam K, Gowda S, Mundkur L (2021) An exploratory study of selenium status in healthy individuals and in patients with COVID-19 in a south Indian population: the case for adequate selenium status. Nutrition 82:111053. https://doi.org/10.1016/j.nut.2020.111053

Malavolta M, Piacenza F, Basso A, Giacconi R, Costarelli L, Mocchegiani E (2015) Serum copper to zinc ratio: relationship with aging and health status. Mech Ageing Dev 151:93-100. https://doi.org/10.1016/j.mad.2015.01.004

Man MA, Rajnoveanu RM, Motoc NS, Bondor CI, Chis AF, Lesan A et al (2021) Neutrophil-to-lymphocyte ratio, platelets-to-lymphocyte ratio, and eosinophils correlation with high-resolution computer tomography severity score in COVID-19 patients. PLoS ONE 16(6):e0252599. https://doi.org/10.1371/journal.pone.0252599

Maqsood M, Dancheck B, Gamble MV, Palafox NA, Ricks MO, Briand K et al (2004) Vitamin A deficiency and inflammatory markers among preschool children in the Republic of the Marshall Islands. Nutr J 3:21. https://doi.org/10. 1186/1475-2891-3-21

Marcinowska-Suchowierska E, Kupisz-Urbańska M, Łukaszkiewicz J, Płudowski P, Jones G (2018) Vitamin D toxicity-A clinical perspective. Front Endocrinol 9:550-550. https://doi.org/10.3389/fendo.2018.00550

Mawson AR (2013) Role of fat-soluble vitamins A and D in the pathogenesis of influenza: a new perspective. ISRN Infect Dis 2013:246737. https://doi.org/10.5402/2013/246737
Mawson AR, Croft AM, Gonzalez-Fernandez F (2021) Liver damage and exposure to toxic concentrations of endogenous retinoids in the pathogenesis of COVID-19 disease: hypothesis. Viral Immunol. https://doi.org/10.1089/vim. 2020.0330

Mitra AK, Alvarez JO, Wahed MA, Fuchs GJ, Stephensen CB (1998) Predictors of serum retinol in children with shigellosis. Am J Clin Nutr 68(5):1088-1094. https://doi. org/10.1093/ajcn/68.5.1088

Moghaddam A, Heller RA, Sun Q, Seelig J, Cherkezov A, Seibert L et al (2020) Selenium deficiency is associated with mortality risk from COVID-19. Nutrients. https://doi. org/10.3390/nu12072098

Muhammad Y, Kani YA, Iliya S, Muhammad JB, Binji A, ElFulaty Ahmad A et al (2021) Deficiency of antioxidants and increased oxidative stress in COVID-19 patients: a cross-sectional comparative study in Jigawa, Northwestern Nigeria. SAGE Open Med 9:2050312121991246. https:// doi.org/10.1177/2050312121991246

Nelson HK, Shi Q, Van Dael P, Schiffrin EJ, Blum S, Barclay D et al (2001) Host nutritional selenium status as a driving force for influenza virus mutations. FASEB J 15(10): 1727-1738

Oh J, Shin SH, Choi R, Kim S, Park HD, Kim SY et al (2019) Assessment of 7 trace elements in serum of patients with nontuberculous mycobacterial lung disease. J Trace Elem Med Biol 53:84-90. https://doi.org/10.1016/j.jtemb.2019. 02.004

Oscanoa TJ, Amado J, Vidal X, Laird E, Ghashut RA, RomeroOrtuno R (2021) The relationship between the severity and mortality of SARS-CoV-2 infection and 25-hydroxyvitamin D concentration - a metaanalysis. Adv Respir Med 89(2):145-157. https://doi.org/10.5603/ARM.a2021.0037

Owen K, Dewald O (2021) Vitamin E toxicity. StatPearls Publishing, FL

Pecora F, Persico F, Argentiero A, Neglia C, Esposito S (2020) The role of micronutrients in support of the immune response against viral infections. Nutrients. https://doi.org/ 10.3390/nu12103198

Peña MM, Lee J, Thiele DJ (1999) A delicate balance: homeostatic control of copper uptake and distribution. J Nutr 129(7):1251-1260. https://doi.org/10.1093/jn/129.7.1251

Peng MY, Liu WC, Zheng JQ, Lu CL, Hou YC, Zheng CM et al (2021) Immunological aspects of SARS-CoV-2 infection and the putative beneficial role of vitamin-D. Int J Mol Sci. https://doi.org/10.3390/ijms22105251

Raha S, Mallick R, Basak S, Duttaroy AK (2020) Is copper beneficial for COVID-19 patients? Med Hypotheses 142:109814. https://doi.org/10.1016/j.mehy.2020.109814

Read SA, Obeid S, Ahlenstiel C, Ahlenstiel G (2019) The role of zinc in antiviral immunity. Adv Nutr 10(4):696-710. https://doi.org/10.1093/advances/nmz013

Rubin LP, Ross AC, Stephensen CB, Bohn T, Tanumihardjo SA (2017) Metabolic effects of inflammation on vitamin A and carotenoids in humans and animal models. Adv Nutr 8(2):197-212. https://doi.org/10.3945/an.116.014167

Rubio CP, Hernández-Ruiz J, Martinez-Subiela S, Tvarijonaviciute A, Ceron JJ (2016) Spectrophotometric assays for total antioxidant capacity (TAC) in dog serum: an update. BMC Vet Res 12(1):166. https://doi.org/10.1186/s12917016-0792-7 
Sarohan AR (2020) COVID-19: endogenous retinoic acid theory and retinoic acid depletion syndrome. Med Hypotheses 144:110250. https://doi.org/10.1016/j.mehy.2020.110250

Sattler S (2017) The role of the immune system beyond the fight against infection. Adv Exp Med Biol 1003:3-14. https:// doi.org/10.1007/978-3-319-57613-8_1

Sepehri Z, Mirzaei N, Sargazi A, Sargazi A, Mishkar AP, Kiani $\mathrm{Z}$ et al (2017) Essential and toxic metals in serum of individuals with active pulmonary tuberculosis in an endemic region. J Clin Tuberc Other Mycobact Dis 6:8-13. https://doi.org/10.1016/j.jctube.2017.01.001

Shah K, Saxena D, Mavalankar D (2021) Vitamin D supplementation, COVID-19 and disease severity: a meta-analysis. QJM: Int J Med 114(3):175-181. https://doi.org/10. 1093/qjmed/hcab009

Shi Y, Wang Y, Shao C, Huang J, Gan J, Huang X et al (2020) COVID-19 infection: the perspectives on immune responses. Cell Death Differ. https://doi.org/10.1038/ s41418-020-0530-3

Skalny AV, Timashev PS, Aschner M, Aaseth J, Chernova LN, Belyaev VE et al (2021) Serum zinc, copper, and other biometals are associated with COVID-19 severity markers. Metabolites 11(4):244. https://doi.org/10.3390/ metabo11040244

Skrobot A, Demkow U, Wachowska M (2018) Immunomodulatory role of vitamin D: a review. Adv Exp Med Biol 1108:13-23. https://doi.org/10.1007/5584_2018_246

Tang AM, Smit E (1998) Selected vitamins in HIV infection: a review. AIDS Patient Care STDS 12(4):263-273. https:// doi.org/10.1089/apc.1998.12.263

Trasino SE (2020) A role for retinoids in the treatment of COVID-19? Clin Exp Pharmacol Physiol 47(10):1765-1767. https://doi.org/10.1111/1440-1681. 13354

Ukleja A, Scolapio J, McConnell J, Spivey J, Dickson R, Nguyen J et al (2002) Nutritional assessment of serum and hepatic vitamin A levels in patients with cirrhosis. J Parenter Enter Nutr 26(3):184-188. https://doi.org/10.1177/ 0148607102026003184

Vogel-González M, Talló-Parra M, Herrera-Fernández V, Pérez-Vilaró G, Chillón M, Nogués X et al (2021) Low zinc levels at admission associates with poor clinical outcomes in SARS-CoV-2 infection. Nutrients. https://doi. org/10.3390/nu13020562

Watkins RR, Lemonovich TL, Salata RA (2015) An update on the association of vitamin $\mathrm{D}$ deficiency with common infectious diseases. Can J Physiol Pharmacol 93(5):363-368. https://doi.org/10.1139/cjpp-2014-0352

Weiss G, Carver PL (2018) Role of divalent metals in infectious disease susceptibility and outcome. Clin Microbiol Infect 24(1):16-23. https://doi.org/10.1016/j.cmi.2017.01.018

Weitkunat R, Wildner M (2002) Exploratory causal modeling in epidemiology: are all factors created equal? J Clin Epidemiol 55(5):436-444

Wenzhong L, Hualan L (2021) COVID-19: captures iron and generates reactive oxygen species to damage the human immune system. Autoimmunity 54(4):213-224. https:// doi.org/10.1080/08916934.2021.1913581
Wessels I, Maywald M, Rink L (2017) Zinc as a gatekeeper of immune function. Nutrients. https://doi.org/10.3390/ nu9121286

Wilhelm G, Benjamin M, Rainer M (2015) Interpretation of statistical significance-exploratory versus confirmative testing in clinical trials, epidemiological studies, metaanalyses and toxicological screening (using Ginkgo biloba as an example). J Clin Exp Pharmacol 5(4):182-187

Winbauer AN, Pingree SS, Nuttall KL (1999) Evaluating serum alpha-tocopherol (vitamin E) in terms of a lipid ratio. Ann Clin Lab Sci 29(3):185-191

Wu Z, McGoogan JM (2020) Characteristics of and important lessons from the coronavirus disease 2019 (COVID-19) outbreak in China: summary of a report of 72314 cases from the Chinese center for disease control and prevention. JAMA. https://doi.org/10.1001/jama.2020.2648

Wu D, Meydani SN (2019) Vitamin E, immune function, and protection against infection. In: Weber $\mathrm{P}$, Birringer $\mathrm{M}$, Blumberg JB, Eggersdorfer M, Frank J (eds) Vitamin E in human health. Springer, Cham, pp 371-384

Wu X, Wang C, Li H, Meng H, Jie J, Fu M et al (2021) Circulating white blood cells and lung function impairment: the observational studies and Mendelian randomization analysis. Ann Med 53(1):1118-1128. https://doi.org/10. 1080/07853890.2021.1948603

Younesian O, Khodabakhshi B, Abdolahi N, Norouzi A, Behnampour N, Hosseinzadeh S et al (2021) Decreased serum selenium levels of COVID-19 patients in comparison with healthy individuals. Biol Trace Elem Res. https:// doi.org/10.1007/s12011-021-02797-w

Yu F, Du L, Ojcius DM, Pan C, Jiang S (2020) Measures for diagnosing and treating infections by a novel coronavirus responsible for a pneumonia outbreak originating in Wuhan, China. Microbes Infect 22(2):74-79. https://doi. org/10.1016/j.micinf.2020.01.003

Zeng HL, Yang Q, Yuan P, Wang X, Cheng L (2021a) Associations of essential and toxic metals/metalloids in whole blood with both disease severity and mortality in patients with COVID-19. FASEB J 35(3):e21392. https://doi.org/ 10.1096/fj.202002346RR

Zeng HL, Zhang B, Wang X, Yang Q, Cheng L (2021b) Urinary trace elements in association with disease severity and outcome in patients with COVID-19. Environ Res 194:110670. https://doi.org/10.1016/j.envres.2020.110670

Zhang L, Liu Y (2020) Potential interventions for novel coronavirus in China: a systematic review. J Med Virol 92(5):479-490. https://doi.org/10.1002/jmv.25707

Zhang J, Taylor EW, Bennett K, Saad R, Rayman MP (2020) Association between regional selenium status and reported outcome of COVID-19 cases in China. Am J Clin Nutr 111(6):1297-1299. https://doi.org/10.1093/ajcn/nqaa095

Publisher's Note Springer Nature remains neutral with regard to jurisdictional claims in published maps and institutional affiliations. 